\title{
STRUT LINKER GEOMETRY IMPROVING MECHANICAL BEHAVIOR OF CORONARY STENT
}

\author{
Rachmat Sriwijaya* \\ Department of Mechanical and Industrial Engineering \\ Faculty of Engineering, Universitas Gadjah Mada \\ Biomedical Engineering \\ Graduate School, Universitas Gadjah Mada \\ Dita Ayu Mayasari \\ Biomedical Engineering \\ Faculty of Engineering, Dian Nuswantoro University \\ Siti Sunarintyas \\ Biomedical Engineering \\ Graduate School, Universitas Gadjah Mada \\ Department of Biomaterials \\ Faculty of Dentistry, Universitas Gadjah Mada \\ Submitted: 27-02-2020; Revised: 26-06-2020; Accepted: 26-06-2020
}

\begin{abstract}
ABSTRAK
Stent adalah salah satu solusi umum yang ditawarkan kepada pasien dengan atherosclerosis. Stent yang ideal harus memiliki sifat mekanik dan biologis yang baik. Penelitian ini bertujuan untuk menganalisis pentingnya geometri strut linker mempengaruhi perilaku mekanik stent terutama pada persentase recoil, foreshortening dan prediksi faktor keamanan terhadap kelelahan stent dengan analisis menggunakan metode elemen hingga. Hasil penelitian menunjukkan bahwa geometri strut linker akan berpengaruh terhadap perilaku mekanik dari stent.
\end{abstract}

Kata kunci: Stent; Atherosclerosis; Strut linker; Recoil.

\begin{abstract}
Stent is one of the common solutions offered to patient with atherosclerosis. An ideal stent should have good mechanical and biological properties. This research aims to analyze the importance of strut linker geometry in influencingmechanical behavior of stent especially on recoil and foreshortening percentages, as well as fatigue safety factor prediction, using finite element analysis. The result indicated that strut linker geometry may influence stent mechanical behavior.
\end{abstract}

Keywords: Stent; Atherosclerosis; Strut Linker; Recoil.

*Corresponding author: sriwijaya@gadjahmada.edu

Copyright $\odot 2020$ THE AUTHOR(S). This article is distributed under a Creative Commons Attribution-Share Alike 4.0 International license. Jurnal Teknosains is published by the Graduate School of Universitas Gadjah Mada. 


\section{INTRODUCTION}

Atherosclerosis is one of the most common causes of morbidity and mortality in industrial and developing countries (Dou et al., 2017). Atherosclerosis is a pathological condition in blood vessels marked by inflammation and plaque formation (Khyza et al., 2017). Plaque formation of atherosclerosis consists of heterogenous lipid-rich necrotic core covered by thin fibrous cap and aggravated by thin-cap fibro-atheroma (van Soest et al., 2017). This plaque causes artery narrowing and decreases blood and oxygen supply to the heart, leading to myocardial infarc and death (Zilberman, 2006). One of the common solutions for atherosclerosis is to perform percutaneous transluminal coronary angioplasty procedure that can restore vessels obstruction. This procedure uses stent that is placed onto catheter balloon and delivered to target location (Zilberman, 2011).

Stent is a coiled wire-mesh tube in small size for holding narrowed blood vessels (Hsiao et al., 2012). Basically, stent consists of two main elements: ring and linker. Linker connects ring, which consists of several struts (Patel et al., 2016). There are two types of stent based on the materials: bare metal stent (BMS) and drug eluting stent (DES) (Meraj et al., 2015). BMS is made of metal alloy without drug substitution, while DES is usually a polymer-based material that containsa particular drug (Ho et al., 2016). In addition to the materials, the geometry of stent also contributes to its mechanical strength. Geometry can increase stent mechanical properties although it is made of the same materials. Basically, there are only two strut shapes of modern stent: crown- and wave-shaped (Sommer et al., 2010). Both strut and linker geometries contribute to stent mechanical strength. They will define stent expansion ability, flexibility, and radial strength (Ho et al., 2016).

The endurance of stent against its surrounding condition in blood vessels has been known to avoid stent failure. Analysis of stent mechanical properties is necessary to improve stent design. This analysis can be conducted using finite element method. Fi- nite element method is one of the methods to solve technical problem. Finite element in analysis and design is a valid and efficient method to investigate and optimize stent mechanical behavior (Debusschere et al., 2015). By using finite element analysis, stent mechanical properties in blood vessels could be investigated to discover the von Mises stress distribution, flexibility, recoil and foreshortening percentage, as well as fatigue safety factor of the stent (Xu et al., 2016)the effect of vascular dynamic bending (VDB.

Nowadays, there are various geometries offered by companies in commercial products. Basically, there are only five models of strut linker geometry in commercial product: I-, U-, V-, S- and N-shaped (Patel et al., 2016). This research is for discovering the best geometry of strut linker in open cell coronary stent made of cobalt-chromium alloy using finite element analysis. $\mathrm{Co}-\mathrm{Cr}$ alloy is one of the common metals in medical devices due to its good mechanical property and biocompatibility. Co-Cr also has better radio-opacity than stainless steel that makes it trackable during delivery process (Ho et al., 2016).

\section{Method \\ Stent Modelling}

Stent was modelled using Autodesk ${ }^{\circledR}$ Inventor Professional 2017. Stent design and dimension were adapted from commercial product. Inner diameter, thickness, and width of the stent were $2.09 \mathrm{~mm}, 0.08 \mathrm{~mm}$, and $0.05 \mathrm{~mm}$, respectively. There are four stents with different strut linker geometry, named I, U, V, and S (Figure 1). The location of strut linker is peak-valley (out-of-phase) with open cell orientation. One stent consists of two sequential crown-rings that are connected with four strut linkers.

\section{Finite Element Model}

Finite element analysis was conducted using Abaqus ${ }^{\circledR}$ software. The model of finite element was adapted from Hsiao et al. (2012) and Mayasari et al. (2018) which consists of five steps: from crimping onto balloon cath- 


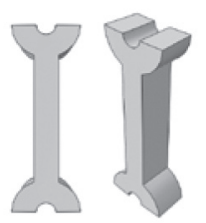

(a)

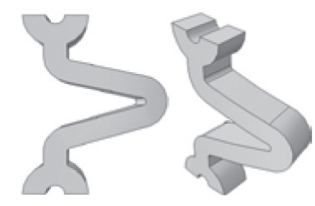

(c)

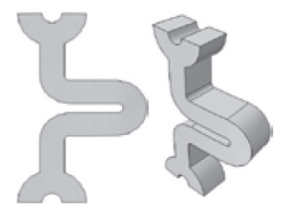

(b)

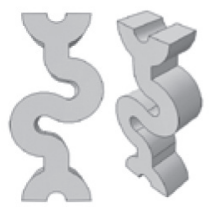

(d)
Figure 1

Four stents with different strut linker geometry:

(a) I-shaped, (b) U-shaped, (c) V-shaped, and (d) S-shaped

eter, stent expansion, recoil and fatigue loading according to systolic/diastolic pressure.

Step 1 : Stent crimping from $2.25 \mathrm{~mm}$ to 1.5 $\mathrm{mm}(\mathrm{OD})$

Step 2: Crimp recoil

Step 3 : Stent expansion to $4.15 \mathrm{~mm}$ (OD)

Step 4 : Expansion recoil

Step 5 : Stent fatigue under 120/80 mmHg systolic/diastolic pressure

The percentage of expansion recoil was stent diameter as calculated between final balloon expansion and after balloon deflation:

$\%$ Expansion recoil $=\frac{D_{\text {step } 3}-D_{\text {step } 4}}{D_{\text {step } 3}}$

The percentage of foreshortening was stent length as calculated between after crimp recoil and after expansion recoil:

$\%$ Foreshortening $=\frac{L_{\text {step } 2}-L_{\text {step } 4}}{L_{\text {step } 3}}$

Crimper and balloon catheter was needed in crimp and expansion process, therefore all components were assembled as seen in Figure 2.

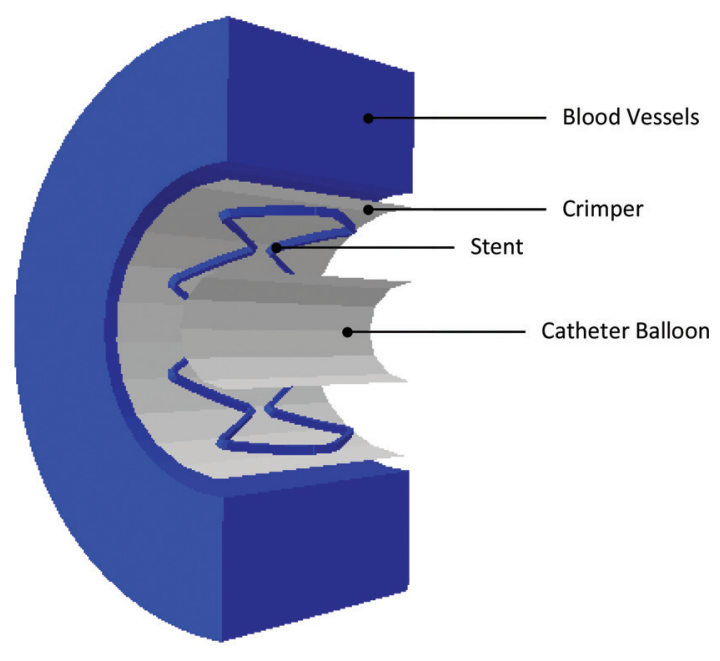

Figure 2.

Crimper and balloon catheter

\section{Material Properties and Boundary Condition}

The material properties of stent used Co-Cr L605 properties with isotropic hardening. The Young's modulus, Poisson ratio and yield stress are $243 \mathrm{GPa}, 0.29$, and $483 \mathrm{MPa}$, respectively. Meanwhile, the material properties of artery used Mooney-Rivlin hyperelastic model. This hyper-elastic model assumed that artery is of isotropic materials.

\section{Mesh Geometry}

Stent model was meshed with 8-node linear brick element in incompatible mode (C3D8I). Furthermore, crimper and catheter balloon were meshed with 4-node quadrilateral surface element, reduced integration (SFM3D4R). An 8-node linear brick, hybrid, constant pressure $(\mathrm{C} 3 \mathrm{D} 8 \mathrm{H})$ was used for meshing the vascular.

\section{Fatigue Safety Factor}

Fatigue safety factor (FSF) distribution was calculated using predicted stress amplitudes and mean stresses by utilizing the Modified-Goodman relation. The FSF was determined as follows: 


$$
\frac{1}{F S F}=\left(\frac{\sigma_{m}}{\sigma_{u}}\right)+\frac{(\Delta \sigma / 2)}{\left(\Delta \sigma_{e} / 2\right)}
$$

Here $\sigma_{m^{\prime}} \sigma_{u}, \Delta \sigma / 2$, and $\Delta \sigma_{e} / 2$ represent zero mean stress, true stresses associated with ultimate tensile strength, stress amplitude, and endurance strength of $\mathrm{Co}-\mathrm{Cr}$ materials (Marrey et al., 2006).

\section{RESULT AND DISCUSSION}

Stent simulation on the vascular was conducted using Abaqus ${ }^{\circledR}$. This simulation resulted in radial displacement, length displacement, contour plot that represent von Mises stress distribution, and maximum principal stress.

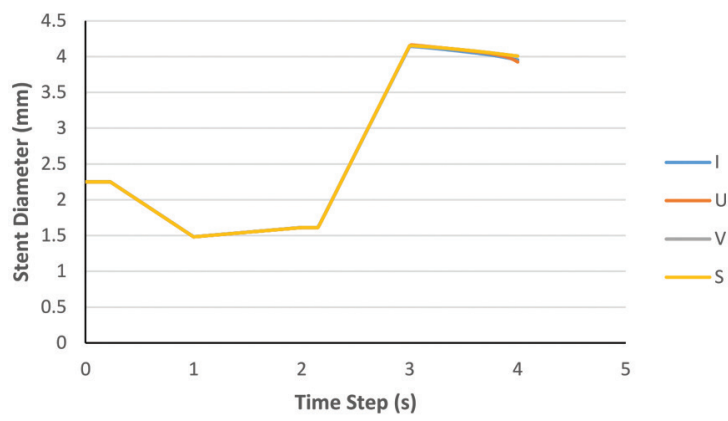

Figure 3.

Diameter of stent changed during simulation

Based on radial displacement, stent diameter was changed during the simulation (Figure 3). The diameter decreased along the crimp step and increased slightly when crimp recoil. Stent diameter increased inline with catheter balloon diameter when balloon inflated. Likewise, stent diameter decreased slightly

when balloon deflated. The change of recoil after crimping was lower than recoil after expansion. This condition could happen because stent contact with hyper-elastic blood vessels after expansion. Therefore, the vessel tends to keep its shape due to its hyper-elastic properties and presses the stent.

The final diameter of stent post-balloon deflation was slightly different to each other which corresponds to the hyper-elastic properties of blood vessels. The changes of stent diameter were used for calculating recoil percentage for each strut linker geometry.

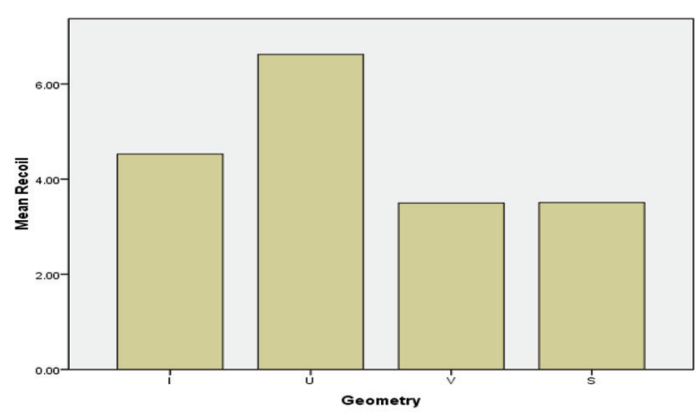

Figure 4.

Recoil of stent structure

Based on Figure 4, the highest recoil percentage was $6.62 \%$ in stent with U-shaped linker, while the lowest one was $3.49 \%$ in stent with V-shaped linker. Radial displacement on stent with U-shaped linker was not uniform.

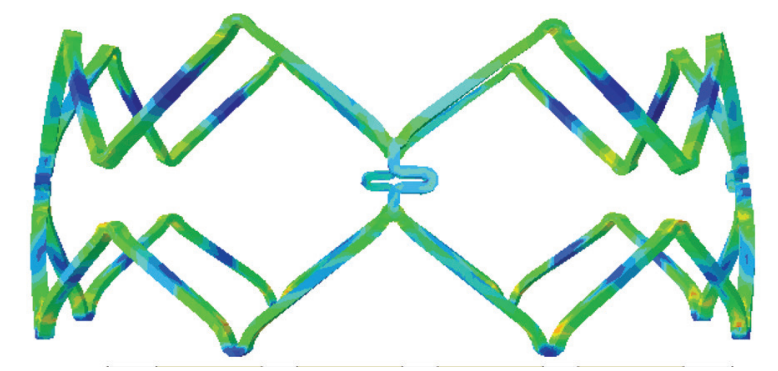

Figure 5.

Radial displacement of U-shaped linker

One of the ends of stent with U-shaped linker has more diameter decrease than another end (Figure 5). The mechanism of how strut linker geometry influenced recoil percentage has not known yet.

The length of stent also changed during the simulation. This change is contradictory to stent diameter. Stent length became longer during crimping and shorter during expansion. The final length of stent after expansion slightly increased. Expansion pressure on the inner surface of stent caused stent foreshortening due to similar stent geometry with double hex geometry which has positive Poisson ratio. Positive Poisson ratio ge- 
ometry is a geometry which has an increase of diameter and a decrease of length while expansion pressure is given (Douglas, 2012).

The changes of stent length were used for calculating foreshortening percentage. As seen in Figure 6 and Figure 5, the highest foreshortening percentage was $29.94 \%$ in S-shaped linker, while the lowest foreshortening was $26.34 \%$ in I-shaped linker. Stent with S-shaped linker has the highest foreshortening percentage because its geometry has more deflection point, allowing it to have more open space.

Therefore, when expansion pressure was applied, the strut was pulled to the ex-

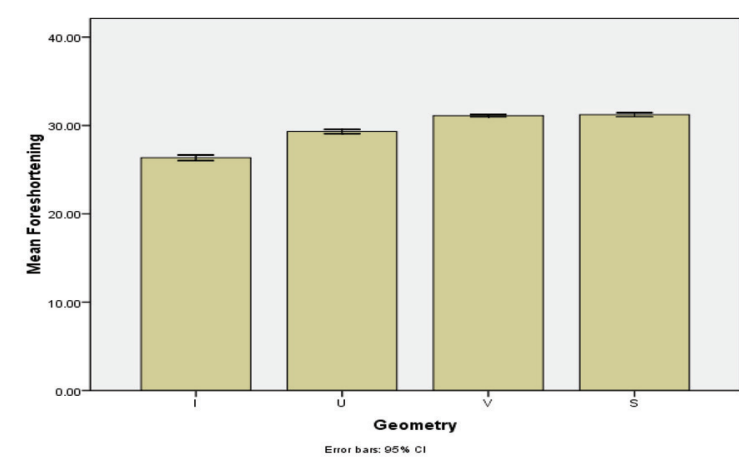

Figure 6.

Foreshortening for each strut linker geometry

pansion direction and caused the strut linker to compact.

Table 1

Fatigue safety factor for each strut linker geometry

\begin{tabular}{l|l|l|l|l|l|l}
\hline $\begin{array}{c}\text { Strut } \\
\text { Linker } \\
\text { Model }\end{array}$ & $\begin{array}{c}\text { Max. Principal } \\
\text { Stress at Systolic } \\
\text { Pressure, 120 } \\
\text { mmHg (MPa) }\end{array}$ & $\begin{array}{c}\text { Max. Principal } \\
\text { Stress at Diastolic } \\
\text { Pressure, 80 mmHg } \\
(\mathbf{M P a})\end{array}$ & $\begin{array}{c}\text { Mean } \\
\text { Stress, om } \\
(\mathbf{M P a})\end{array}$ & $\begin{array}{c}\text { Stress } \\
\text { Amplitude, } \\
\Delta \sigma / 2 \text { (MPa) }\end{array}$ & $\begin{array}{c}\text { Inverse } \\
\text { Fatigue Safety } \\
\text { Factor (1/FSF) }\end{array}$ & $\begin{array}{c}\text { Fatigue Safety } \\
\text { Factor (FSF) }\end{array}$ \\
\hline $\mathrm{I}$ & 636.2 & 617.0 & 626.6 & 9.6 & 0.48 & 2.09 \\
\hline $\mathrm{U}$ & 649.2 & 650.6 & 649.9 & 0.7 & 3.14 & 0.32 \\
\hline $\mathrm{V}$ & 639.1 & 640.5 & 639.8 & 0.7 & 0.44 & 2.25 \\
\hline $\mathrm{S}$ & 554.9 & 556.1 & 555.5 & 0.6 & 0.38 & 2.59 \\
\hline
\end{tabular}

In this research, additional systole-diastole pressure was used to predict fatigue safety factor (FSF). The prediction of FSF was calculated using maximum principal stress prediction. The result for each strut linker geometry is listed in Table 1. The lowest FSF prediction was on the stent with U-shaped linker. The small value of FSF shows the low endurance of stent against systole and diastole, thus it would be easy to fracture on that element.

\section{CONCLUSION}

Finite element analysis of several stents with different strut linker shapes was conducted in this research. It was revealed that strut linker geometry has pivotal role to get an ideal stent with low recoil and foreshortening percentage due to its duty to prevent blood vessel from narrowing. Further study is still needed to evaluate the flexibility on each stent with its different strut linker geometry.

\section{Acknowledgements}

The authors thank those at Universitas Gadjah Mada and Dian Nuswantoro University who have contributed to this research.

\section{BIBLIOGRAPHY}

Debusschere, N., Segers, P., Dubruel, P., Verhegghe, B. and De Beule, M., 2015. A finite element strategy to investigate the free expansion behaviour of a biodegradable polymeric stent. Journal of biomechanics, 48(10), pp.20122018.

Douglas, G.R., 2012. Design of stent expansion mechanisms (Doctoral dissertation, University of British Columbia). 
Dou, Y., Chen, Y., Zhang, X., Xu, X., Chen, Y., Guo, J., Zhang, D., Wang, R., Li, $X$. and Zhang, J., 2017. Non-proinflammatory and responsive nanoplatforms for targeted treatment of atherosclerosis. Biomaterials, 143, pp.93-108.

Ho, M.Y., Chen, C.C., Wang, C.Y., Chang, S.H., Hsieh, M.J., Lee, C.H., Wu, V.C.C. and Hsieh, I., 2016. The development of coronary artery stents: from bare-metal to bio-resorbable types. Metals, 6(7), p.168.

Hsiao, H.M., Chiu, Y.H., Lee, K.H. and Lin, C.H., 2012. Computational modeling of effects of intravascular stent design on key mechanical and hemodynamic behavior. Computer-aided design, 44(8), pp.757-765.

Khyzha, N., Alizada, A., Wilson, M.D. and Fish, J.E., 2017. Epigenetics of atherosclerosis: emerging mechanisms and methods. Trends in Molecular Medicine, 23(4), pp.332-347.

Mayasari, D.A., Sriwijava, R., Siswomiharjo, W. and Sunarintyas, S., 2018, August. Free Expansion Behaviour of Coronary Stent Based on Strut Linker Geometry. In 2018 4th International Conference on Science and Technology (ICST) (pp. 1-4). IEEE.

Marrey, R.V., Burgermeister, R., Grishaber, R.B. and Ritchie, R.O., 2006. Fatigue and life prediction for cobalt-chromium stents: A fracture mechanics analysis. Biomaterials, 27(9), pp.19882000 .
Meraj, P.M., Jauhar, R. and Singh, A., 2015. Bare metal stents versus drug eluting stents: where do we stand in 2015?. Current treatment options in cardiovascular medicine, 17(8), p.39.

Patel, S.M., Li, J. and Parikh, S.A., 2016. Design and Comparison of Large Vessel Stents: Balloon Expandable and Self-Expanding Peripheral Arterial Stents. Interventional cardiology clinics, 5(3), pp.365-380.

Sommer, C.M., Grenacher, L., Stampfl, U., Arnegger, F.U., Rehnitz, C., Thierjung, H., Stampfl, S., Berger, I., Richter, G.M., Kauczor, H.U. and Radeleff, B.A., 2010. Impact of stent design on in-stent stenosis in a rabbit iliac artery model. Cardiovascular and interventional radiology, 33(3), pp.565575.

vanSoest, G., Marcu, L., Bouma, B.E. and Regar, E., 2017. Intravascular imaging for characterization of coronary atherosclerosis. Current Opinion in Biomedical Engineering, 3, pp.1-12.

Xu, J., Yang, J., Huang, N., Uhl, C., Zhou, Y. and Liu, Y., 2016. Mechanical response of cardiovascular stents under vascular dynamic bending. Biomedical engineering online, 15(1), p.21.

Zilberman M, ed. 2006. Studies in mechanobiology, tissue engineering and biomaterials. Springer.

Zilberman, M. ed., 2011. Active implants and scaffolds for tissue regeneration (pp. 1-24). Berlin, Germany: Springer. 